\title{
Mathematical Modelling of Drying of Chlorella sp., Neochloris conjuncta and Botryococcus braunii at Different Drying Conditions
}

\author{
Sevil Karaaslan', Onder Uysal ${ }^{1}$, F. Ozge Uysal ${ }^{2}$, Kamil Ekinci ${ }^{1 *}$ and B. Salih \\ $\mathrm{Kumbul}^{1}$
}

\begin{abstract}
Drying is one of the most important process in the cultivation of microalgae. Performance of drying depends on appropriate drying methods. This study aimed (1) to determine the effect of different drying methods on the Chlorella sp., Neochloris conjuncta, and Botryococcus braunii strains and (2) to identify the most suitable model for drying methods.

Chlorella sp., Neochloris conjuncta and Botryococcus braunii cultures were grown in basal medium in raceways at the greenhouse condition in Isparta province. During experiment, air temperature and relative humidity, wind speed, solar irradiance, wet and dry mass and temperature of microalgae biomass were measured. Drying applications continued for approximately 3 days.

Microalgae were dried at solar tunnel, outdoor, and greenhouse conditions. Furthermore, the effect of drying methods such as open sun, solar tunnel, and greenhouse drying on drying time, and drying ratio of microalgae have been investigated. The drying data were applied to ten different mathematical models, namely, Newton, Page, Henderson and Pabis, Logarithmic, Midilli and Kucuk, Wang and Singh, Two Term, Two Term Exponential, Weibull and Logistic Equation Models. The performance of these models were compared according to the coefficient of determination, standard error of estimate and residual sum of squares, between the observed and predicted moisture ratios. Results showed that the Weibull equation gave the best prediction to the drying kinetics evidenced by coefficient of determination ranging from $0.9959-0.9992$ for all drying methods. In addition, solar tunnel drying method has been determined to be the most suitable one among tested methods for drying of microalgae.
\end{abstract}

Key words: Chlorella sp., Neochloris conjuncta, Botryococcus braunii, drying, mathematical modelling, microalgae

\section{Introduction}

Drying of agricultural crops has always been of great importance to the conservation of food by human beings. Sun-drying is still the most common method used to preserve agricultural products in most tropical and subtropical countries. Sun drying is only possible in areas where, in an average year, the weather allows foods to be dried immediately after harvest. The main advantages of sun drying are low capital and operating costs and the fact that little expertise is required. Even though sun drying offers inexpensive way of drying operation, agricultural products are exposed to uncontrolled weather conditions and to the attack of insect, pests, microorganisms, and dust (Bala et al., 2003) and harmful effects of UV radiation (Stiling et al., 2012). The resulting loss of food quality in the dried products may have adverse economic effects on domestic and international markets (Imre, 1986; Tiriş et al., 1994). The introduction of

Suleyman Demirel University, Agriculture Faculty, Department of Agricultural Machinery, Isparta/Turkey.

2 GPA Muhendislik Ltd. Co., Isparta, Turkey. *Corresponding author. 
solar dryers in developing countries can reduce crop losses and improve the quality of the dried product significantly when compared to the traditional methods of drying such as sun or shade drying. Additionally, solar tunnel dryer can be operated by a fan driven by photovoltaic module and this system removes moisture inside dryer. Solar tunnel dryer was utilized for drying of many agricultural products such as fruits, vegetables, cereals, grain, legumes, oil seeds, spices and even fish and meat (Bala et al., 2003). Due to the rich content of microalgae, they could be used in different sectors such as food, agriculture, cosmetics and biofuels. Microalgae biomass should be dried for many applications. Since conventional drying methods increases the cost of microalgae biomass, exploitation of solar as an alternative energy source is considered to be economic for the drying process. Therefore, in this study low-cost drying applications such as solar tunnel, open sun, and greenhouse drying methods were applied to dry microalgae biomass. This study aimed (1) to determine the effect of different drying methods on the Chlorella sp., Neocbloris conjuncta and Botryococcus braunii strains in Isparta province and (2) to determine the best describing mathematical model to experimental data.

\section{Materials and Methods Experimental materials}

Chlorella sp., Neochloris conjuncta and Botryococcus braunii cultures were grown in basal medium with raceways in the greenhouse condition at the Department of Agricultural Machinery and Technologies Engineering at Suleyman Demirel University in Isparta province. Chlorella sp. (SAG 241.80), Botryococcus braunii (SAG 807-1) and Neocbloris conjuncta (SAG 78.80) were cultivated in erlenmeyers $(500 \mathrm{ml}-2 \mathrm{~L}$ ) and reactors $(10 \mathrm{~L}-50 \mathrm{~L})$ in laboratory conditions. Basal medium was selected as the nutrient medium. The final $\mathrm{pH}$ of this medium was 7.0 after being autoclaved. The algal cells were grown at a temperature of $25 \pm 1^{\circ} \mathrm{C}$ and PAR (Photosynthetically Active Radiation) of $125 \mu \mathrm{mol} \mathrm{m} \mathrm{m}^{-2} \mathrm{~s}^{-1}$ measured by Delta Ohm PAR meter. Cultures were transferred to the raceway when the desired density was reached. 50 liters of culture in the laboratory were transferred to 250 liters reactors in the greenhouse $(6 \times 5 \mathrm{~m})$. Afterwards, cultures were transferred to three-1.5 ton capacity-raceways separately. Seven days later, the microalgae biomasses were obtained and harvested. The gravimetric moisture content of microalgae cultures were determined as $79.6,70.9$ and $82.4 \%$ w.b. for Chlorella sp., Neocbloris conjuncta and Botryococcus braunii, respectively using standard method at $105^{\circ} \mathrm{C}$ for 24 hours.

\section{Drying methods}

A solar tunnel dryer constructed at Department of Agricultural Machinery and Technologies Engineering at Suleyman Demirel University was used in this study (Figure 1). It comprised of a flat plate solar collector, a drying tunnel, a solar cell module, and a small axial fan. All units are mounted on metal frame. The bottom of solar collector has hexagonal channels and is directly connected to drying tunnel. The bottom of solar tunnel dryer is painted black to absorb radiation. The collector is coated with a 
transparent polycarbonate material. The dryer is equipped with a $150 \mathrm{~W}$ solar cell module. A fan delivers air to the drying tunnel. Solar energy absorption area of the collector is $2 \mathrm{~m}$ length and $1.9 \mathrm{~m}$ width. The drying tunnel area is twice the area of collector. The dryer is oriented in east-west direction and its drying tunnel is not shaded by trees or buildings between 9:00 am and 5:00 pm.

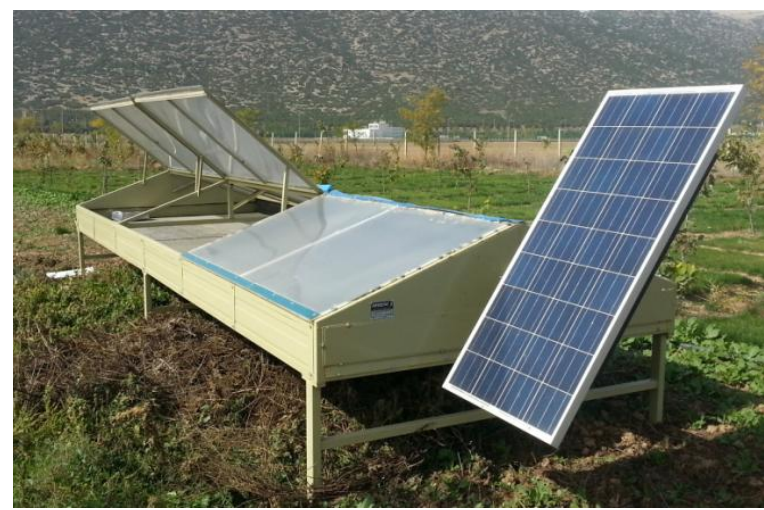

Figure 1. The experimental solar tunnel dryer

A greenhouse constructed at Department of Agricultural Machinery and Technologies Engineering at Suleyman Demirel University was used for greenhouse drying in this study. The dimensions of greenhouse is $6 \times 5$ meter $\left(30 \mathrm{~m}^{2}\right)$. Three raceways were located at the same greenhouse. Additionally, the cultures were dried under open sun drying during all day $\left(32-39^{\circ} \mathrm{C}\right)$.

\section{Drying procedure}

During experiment, air temperature and relative humidity, wind speed, solar irradiance, wet and dry mass and temperature of microalgae biomass were measured. The drying was carried out with three replications for each drying methods. Drying application continued for approximately 3 days. Drying experiment started after the completion of the loading at 9:00 am and was paused at 5:00 pm for each day. Weight loss of the microalgae in the solar tunnel dryer was measured during the drying period at four hour intervals with a digital balance. In the afternoon after 5:00 pm, the cultures of microalgae in the solar tunnel dryer were kept in the dryer in the environmental conditions. Then, cultures were exposed to the same weather conditions. The drying process was terminated until no mass change was detected. Experiments were carried out on September 9-11, 2015. Solar irradiance were measured hourly (09:00 am- 17:00 pm) on a horizontal surface by pyranometer. Relative humidity and temperature of drying air were measured using K type thermocouples and DT-3 hygrometer at the drying tunnel of dryer. Air velocity at the outlet of drying tunnel was measured by a hotwire anemometer. Chlorella sp., Neochloris conjuncta and Botryococcus braunii microalgae cultures were distributed uniformly in a thin layer in plates, and then exposed to open sun, solar 
tunnel, and greenhouse drying conditions. The moisture content for each sample was measured at interval of 4 hours each, until equilibrium is maintained.

\section{Mathematical modelling of the drying curves}

Drying curves were fitted with 10 thin layer drying models, namely, Newton, Page, Henderson and Pabis, Logarithmic, Midilli and Kucuk, Wang and Singh, Two Term, Two Term Exponential, Weibull and Logistic Equation Models (Table 1).

The moisture ratio (MR) of microalgae cultures was calculated based on moisture content as a function of time $(\mathrm{t})(\mathrm{M}(\mathrm{t}))$, initial moisture content of cultures $\left(\mathrm{M}_{0}\right)$, and equilibrium moisture content of cultures $\left(\mathrm{M}_{\mathrm{e}}\right)$.

$$
\mathrm{MR}=\frac{\mathrm{M}(\mathrm{t})-\mathrm{M}_{\mathrm{e}}}{\mathrm{M}_{0}-\mathrm{M}_{\mathrm{e}}}
$$

All moisture contents were reported as wet basis (wb.\%). Simplification of MR in Eq. (1) as M/Mo was suggested by Diamente and Munro, 1993; Elicin and Sacilik, 2005 due to the continuous fluctuation of relative humidity of drying air under solar tunnel dryer conditions. Therefore, the drying rate as $g_{\text {water }} / \mathrm{h}$ (DR) of the microalgae cultures were determined by Eq. (2):

$$
\mathrm{DR}=\frac{\mathrm{M}_{\mathrm{t}+\mathrm{dt}}-\mathrm{M}_{\mathrm{t}}}{\mathrm{dt}}
$$

Where $\mathrm{M}_{\mathrm{t}+\mathrm{dt}}$ is the moisture content at $t+\mathrm{d} t$ ( $\mathrm{g}_{\text {water }} / \mathrm{g}_{\text {dry }}$ matter $)$. A non-linear regression analysis (Sigma Plot 12.00) was applied to experimentally obtained MR as a function of time using drying models given in Table 1. The constants ( $a, n, b, c, m, k$, and g) of models tested in Table 1 were determined based on the non-linear regression analysis. The performance of models was evaluated by coefficient of determination $\left(\mathrm{R}^{2}\right)$, the standard error of estimate (SEE), and residual sum of square (RSS).

\begin{tabular}{|c|c|c|c|}
\hline No & Model name & Model Equation & References \\
\hline 1 & Newton & $\mathrm{MR}=\exp (-\mathrm{kt})$ & Toğrul and Pehlivan 2002 \\
\hline 2 & Page & $\mathrm{MR}=\exp \left(-\mathrm{kt}^{\mathrm{n}}\right)$ & Akpinar 2008 \\
\hline 3 & Henderson and pabis & $M R=a \exp (-k t)$ & Doymaz, 2014 \\
\hline 4 & Logarithmic & $M R=a \exp (-k t)+c$ & Akpinar 2008 \\
\hline 5 & Midilli et al. & $\mathrm{MR}=\mathrm{a} \exp \left(-\mathrm{k} \mathrm{t}^{\mathrm{m}}\right)+\mathrm{b} \mathrm{t}$ & Midilli et al. 2002 \\
\hline 6 & Wang and Singh & $\mathrm{MR}=1+\mathrm{at}+\mathrm{bt}^{2}$ & Babalis et al. 2006 \\
\hline 7 & Two term & $M R=a \exp \left(-k_{0} t\right)+b \exp \left(-k_{1} t\right)$ & Yaldiz et al.2001 \\
\hline 8 & Two term exponential & $M R=a \exp (-k t)+(1-a) * \exp \left(-m^{*} k^{*} x\right)$ & Sharaf-Elden et al. 1980 \\
\hline 9 & Weibull distribution & $M R=a-b \exp \left[-\left(k t^{n}\right)\right]$ & Babalis et al. 2006 \\
\hline 10 & Logistic & $\mathrm{MR}=\mathrm{a}_{0} /(1+\mathrm{a} \exp (\mathrm{kt}))$ & Soysal 2005 \\
\hline
\end{tabular}

Table 1. Mathematical models tested for the moisture ratio values of the microalgae cultures

\section{Results and discussion}


Solar drying of microalgae cultures was conducted on September in 2015. Throughout the experiment, the weather was sunny and no rain was recorded. The experiment lasted for approximately 3 days. Figure 2 shows the change of solar irradiance during the experiment. The influence of different drying conditions of microalgae cultures on moisture ratio, drying rate values were also investigated.

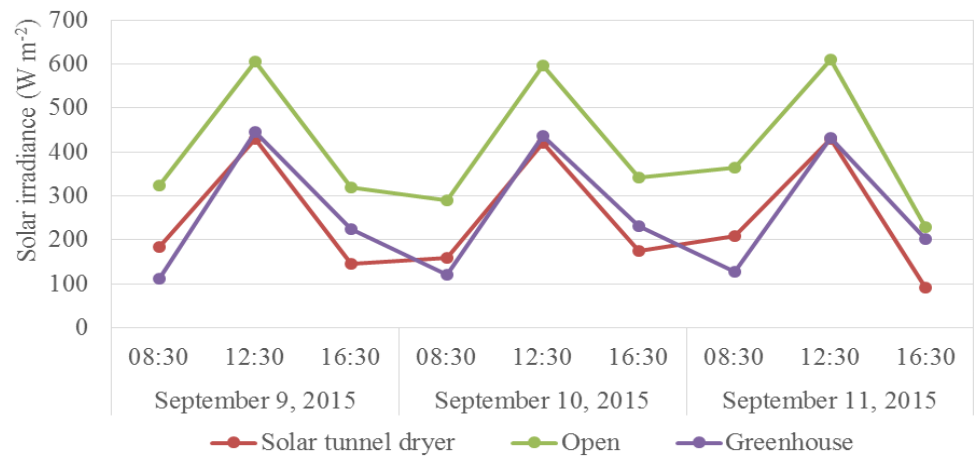

Figure 2. Solar irradiance level

The drying curves of microalgae cultures using different drying conditions are shown in Figure 3, 4, and 5. In all figures, C, N, and B stands for Chlorella sp., Neocbloris conjuncta and Botryococcus braunii microalgae cultures, respectively. When the moisture content decreased, the moisture ratio continuously decreased. The drying time necessary for reduction of initial moisture content from $(79.66 \%)$ to the desired final moisture content up to $(19.47,20.55$ and $20.70 \%$ ) for Chlorella sp. microalgae cultures at solar tunnel drying, open sun drying and greenhouse drying was found to be 56 hours. The times taken for drying of Neochloris conjuncta microalgae cultures from the initial moisture content of $70.9 \%$ to final moisture content of around 20.88, 20.59 and $21.65 \%$ were 56 hours while drying time for Botryococcus brannii microalgae cultures from the initial moisture content of $82.42 \%$ to final moisture content of $13.54,13.54$ and $15.90 \%$ were 56 hours in solar tunnel drying, open sun drying and green house drying, respectively. Experimental and predicted moisture ratio values with drying time obtained from the Weibull Model are shown in Figure 3, 4, and 5.

The drying rate defined as the quantity of water removed with time is shown in Figure 6, 7 , and 8 for different microalgae at solar tunnel, open sun and greenhouse drying. The total drying rates to reach the final moisture content were $2.51,2.49$, and $3.01 \mathrm{~g}$ water $/ \mathrm{h}$ at Chlorella sp., Neocbloris conjuncta and Botryococcus braunii microalgae cultures for solar tunnel drying, respectively (Figure 6). The drying rate is shown in Figure 7 for Cblorella sp., Neocbloris conjuncta and Botryococcus braunii microalgae cultures during open sun drying. The results were 1.77, 1.86, and $2.68 \mathrm{~g}_{\text {water }} /$ hour for Cblorella sp., Neochloris conjuncta and Botryococcus brannii microalgae cultures at open sun drying, respectively. The drying rate sharply increased within four and eight hours and then decreased. As can be seen in Figure 8, the drying rates of Chlorella sp., Neocbloris conjuncta and Botryococcus braunii microalgae cultures for greenhouse drying took $1.63,1.76$, and $1.77 \mathrm{~g}_{\text {water }} / \mathrm{h}$, respectively. This behavior was periodic and gradually diminishing in magnitude on each day of 
drying. It can be said that the drying rate of all dried microalgae cultures at solar tunnel drying was higher than that of all dried microalgae in open sun and greenhouse dryer.

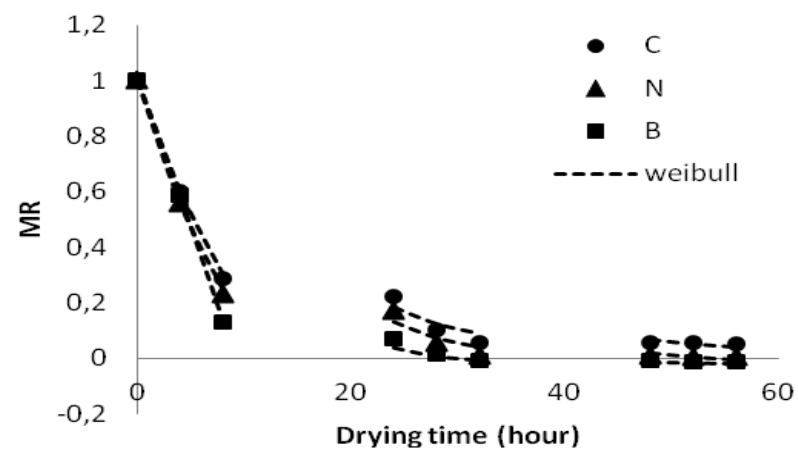

Figure 3. Variation of experimental and predicted moisture ratios with drying time for solar tunnel drying of microalgae (Weibull Model)

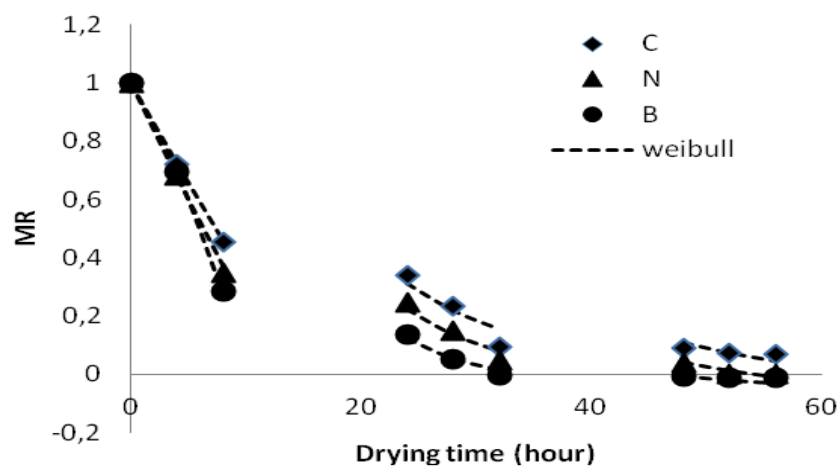

Figure 4. Variation of experimental and predicted moisture ratios with drying time for open sun drying of microalgae (Weibull Model)

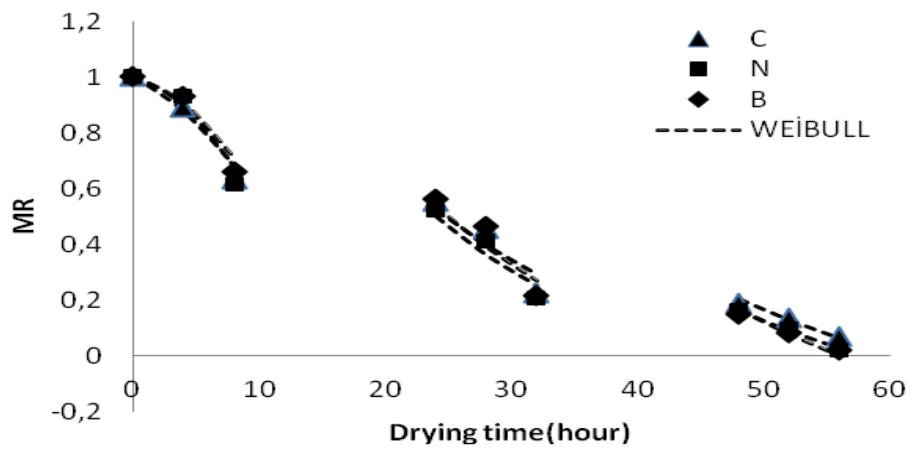

Figure 5. Variation of experimental and predicted moisture ratios with drying time for greenhouse drying of microalgae (Weibull Model) 


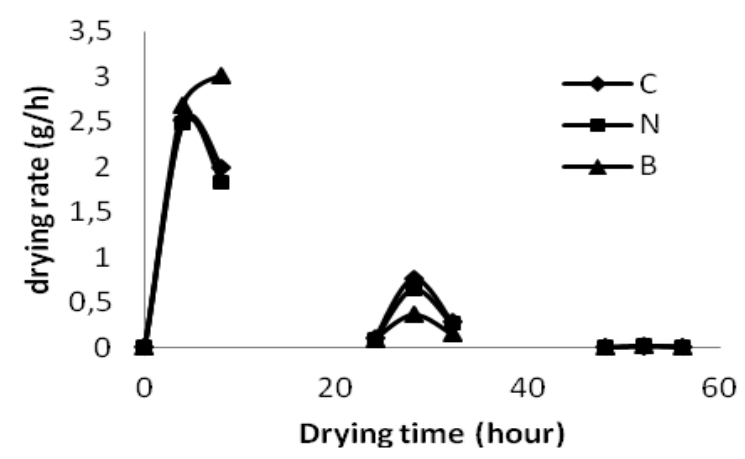

Figure 6. Variation of drying rate as a function of drying time for solar tunnel drying of microalgae

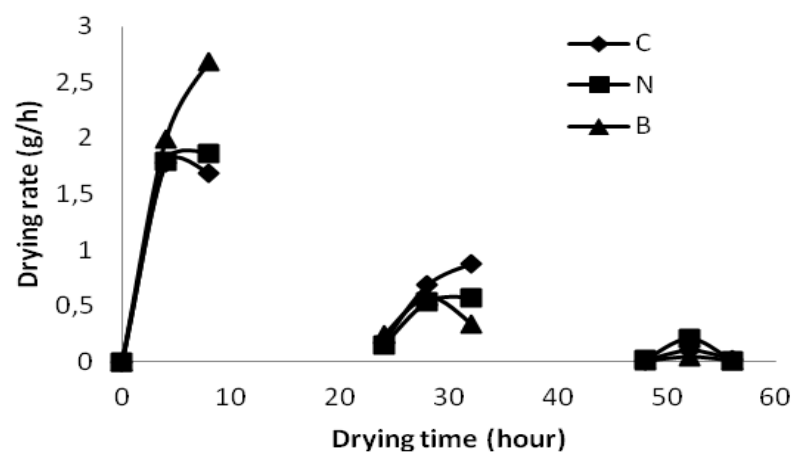

Figure 7. Variation of drying rate as a function of drying time for open sun drying of microalgae

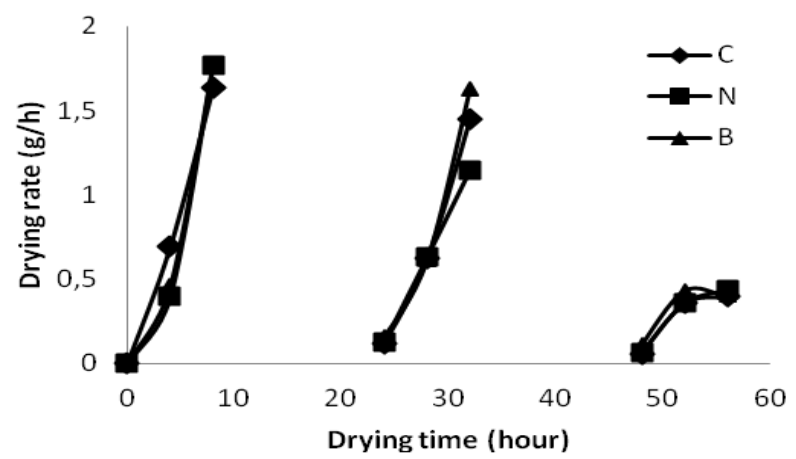

Figure 8. Variation of drying rate as a function of drying time for greenhouse drying of microalgae

Non-linear regression analysis was performed using the sigma plot computer program. $\mathrm{R}^{2}$ was one of the important criteria for selecting the best model to define the drying curves of microalgae cultures. Besides $\mathrm{R}^{2}$, the various statistical parameters such as SEE and RSS are used to evaluate the goodness of fit of the models. Therefore, the lower the SEE and RSS values and the higher $\mathrm{R}^{2}$ values were used to determine the quality of the 
fit. The statistical analyses results applied to these models at drying process at solar tunnel, open sun and greenhouses drying are given in Tables 2, 3 and 4 for microalgae cultures. The results of the statistical computations undertaken to assess the consistency of 10 drying models are presented in Tables 2, 3 and 4 for the Weibull Distribution model. The Weibull Distribution model yielded the highest values of $\mathrm{R}^{2}$ and the lowest values of SEE and RSS. To take into account the effect of the drying variables on the Weibull Distribution model constants $a, b, k$ and $n$ were regressed against those of drying air temperatures using multiple regression analysis. Based on the multiple regression analysis, the accepted model was as follows:

$$
\operatorname{MR}(a, b, k, n)=\frac{M-M_{e}}{M_{0}-M_{e}}=\mathrm{a}-\mathrm{b} \exp \left[-\left(\mathrm{kt}^{\mathrm{n}}\right)\right]
$$

(5)

Table 2. Non-linear regression analysis results for solar tunnel drying of microalgae cultures.

\begin{tabular}{|c|c|c|c|c|c|c|c|c|c|}
\hline & C & & & $\mathbf{N}$ & & & B & & \\
\hline & $\mathbf{R}^{2}$ & SEE & RSS & $\mathbf{R}^{2}$ & SEE & RSS & $\mathbf{R}^{2}$ & SEE & RSS \\
\hline Newton & 0.9911 & 0.0308 & 0.0076 & 0.9948 & 0.0246 & 0.0048 & 0.9720 & 0.0602 & 0.0290 \\
\hline Page & 0.9915 & 0.0321 & 0.0072 & 0.9957 & 0.0237 & 0.0039 & 0.9963 & 0.0233 & 0.0038 \\
\hline $\begin{array}{l}\text { Henderson and } \\
\text { pabis }\end{array}$ & 0.9911 & 0.0330 & 0.0076 & 0.9949 & 0.0260 & 0.0047 & 0.9731 & 0.0631 & 0.0279 \\
\hline Logarithmic & 0.9944 & 0.0283 & 0.0048 & 0.9951 & 0.0275 & 0.0045 & 0.9793 & 0.0599 & 0.0215 \\
\hline Midilli -Kucuk & 0.9955 & 0.0276 & 0.0038 & 0.9958 & 0.0279 & 0.0039 & 0.9967 & 0.0260 & 0.0034 \\
\hline Wang And Singh & 0.9537 & 0.0750 & 0.0393 & 0.9404 & 0.0887 & 0.0550 & 0.9171 & 0.1108 & 0.0860 \\
\hline Two term & 0.9951 & 0.0289 & 0.0042 & 0.9949 & 0.0308 & 0.0047 & 0.9731 & 0.0747 & 0.0279 \\
\hline $\begin{array}{ll}\text { Two term } \\
\text { exponential }\end{array}$ & 0.9951 & 0.0265 & 0.0042 & 0.9948 & 0.0284 & 0.0048 & 0.9720 & 0.0695 & 0.0290 \\
\hline $\begin{array}{l}\text { Weibull } \\
\text { distribution }\end{array}$ & 0.9959 & 0.0265 & 0.0035 & 0.9964 & 0.0256 & 0.0033 & 0.9991 & 0.0133 & 0.0009 \\
\hline Logistic & 0.9911 & 0.0356 & 0.0076 & 0.9957 & 0.0258 & 0.0040 & 0.9968 & 0.0234 & 0.0033 \\
\hline
\end{tabular}

Table 3. Non-linear regression analysis results for open sun drying of microalgae cultures.

\begin{tabular}{|c|c|c|c|c|c|c|c|c|c|}
\hline & $\mathrm{C}$ & & & $\mathbf{N}$ & & & $\mathbf{B}$ & & \\
\hline & $\overline{\mathbf{R}^{2}}$ & SEE & RSS & $\overline{\mathbf{R}^{2}}$ & SEE & RSS & $\overline{\mathbf{R}^{2}}$ & SEE & RSS \\
\hline Newton & 0.9933 & 0.0270 & 0.0058 & 0.9932 & 0.0307 & 0.0124 & 0.9718 & 0.0619 & 0.0307 \\
\hline Page & 0.9942 & 0.0269 & 0.0051 & 0.9956 & 0.0246 & 0.0042 & 0.9972 & 0.0208 & 0.0030 \\
\hline $\begin{array}{l}\text { Henderson and } \\
\text { pabis }\end{array}$ & 0.9935 & 0.0283 & 0.0056 & 0.9919 & 0.0335 & 0.0079 & 0.9742 & 0.0633 & 0.0281 \\
\hline Logarithmic & 9935 & 0.0305 & 0.0056 & 0.9947 & 0.0293 & 0.0052 & 0.9837 & 0.0544 & 0.0178 \\
\hline Midilli-Kucuk & 9952 & 0.0289 & 0.0042 & 0.9958 & 0.0284 & 0.0040 & 0.9978 & 0.0220 & 0.0024 \\
\hline Wang And Singh & 0.9921 & 0.0313 & 0.0069 & 0.9798 & 0.0528 & 0.0195 & 0.9728 & 0.0650 & 0.0296 \\
\hline Two term & 0.9935 & 0.0335 & 0.0056 & 0.9919 & 0.0396 & 0.0079 & 0.9742 & 0.0749 & 0.0281 \\
\hline $\begin{array}{ll}\text { Two } & \text { term } \\
\text { exponential } & \end{array}$ & 0.9933 & 0.0312 & 0.0058 & 0.9912 & 0.0377 & 0.0085 & 0.9718 & 0.0715 & 0.0307 \\
\hline $\begin{array}{l}\text { Weibull } \\
\text { distribution }\end{array}$ & 0.9934 & 0.0338 & 0.0057 & 0.9974 & 0.0223 & 0.0025 & 0.9992 & 0.0133 & 0.0009 \\
\hline Logistic & 0.9941 & 0.0292 & 0.0051 & 0.9953 & 0.0276 & 0.0046 & 0.9970 & 0.0234 & 0.0033 \\
\hline
\end{tabular}

Table 4. Non-linear regression analysis results for greenhouse drying of microalgae cultures. 


\begin{tabular}{|c|c|c|c|c|c|c|c|c|c|}
\hline & $\mathbf{C}$ & & & $\mathbf{N}$ & & & $\bar{B}$ & & \\
\hline & $\overline{\mathbf{R}^{2}}$ & SEE & RSS & $\overline{\mathbf{R}^{2}}$ & SEE & RSS & $\overline{\mathbf{R}^{2}}$ & SEE & RSS \\
\hline Newton & 0.9594 & 0.0673 & 0.0362 & 0.9462 & 0.0826 & 0.0546 & 0.9278 & 0.0979 & 0.0768 \\
\hline Page & 0.9862 & 0.0420 & 0.0123 & 0.9861 & 0.0449 & 0.0141 & 0.9848 & 0.0480 & 0.0162 \\
\hline $\begin{array}{l}\text { Henderson and } \\
\text { pabis }\end{array}$ & 0.9669 & 0.0650 & 0.0295 & 0.9580 & 0.0780 & 0.0426 & 0.9423 & 0.0936 & 0.0614 \\
\hline Logarithmic & 0.9842 & 0.0484 & 0.0141 & 0.9829 & 0.0537 & 0.0173 & 0.9825 & 0.0557 & 0.0186 \\
\hline Midilli-Kucuk & 0.9867 & 0.0487 & 0.0119 & 0.9873 & 0.0508 & 0.0129 & 0.9874 & 0.0519 & 0.0134 \\
\hline Wang And Singh & 0.9846 & 0.0443 & 0.0137 & 0.9810 & 0.0512 & 0.0184 & 0.9810 & 0.0537 & 0.0202 \\
\hline Two term & 0.9669 & 0.0769 & 0.0295 & 0.9580 & 0.0923 & 0.0426 & 0.9423 & 0.1108 & 0.0614 \\
\hline $\begin{array}{ll}\text { Two } & \text { term } \\
\text { exponential } & \end{array}$ & 0.9594 & 0.0777 & 0.0362 & 0.9462 & 0.0954 & 0.0546 & 0.9278 & 0.1131 & 0.0768 \\
\hline $\begin{array}{l}\text { Weibull } \\
\text { distribution }\end{array}$ & 0.9868 & 0.0485 & 0.0118 & 0.9898 & 0.0454 & 0.0103 & 0.9876 & 0.0514 & 0.0132 \\
\hline Logistic & 0.9863 & 0.0451 & 0.0122 & 0.9850 & 0.0504 & 0.0152 & 0.9848 & 0.0519 & 0.0161 \\
\hline
\end{tabular}

\section{Conclusions}

Chlorella sp., Neochloris conjuncta and Botryococcus braunii microalgae cultures were dried using a solar tunnel dryer, open sun and greenhouse methods. During the experiment, relative humidity and temperature of drying air, solar irradiation, moisture reduction from Chlorella sp., Neocbloris conjuncta and Botryococcus braunii microalgae cultures were measured. All microalgae cultures were dried in the same drying time. The drying rate of all dried microalgae cultures at solar tunnel drying was higher than that of all dried microalgae cultures in open sun and greenhouse dryer. Among the all model tested, Weibull Model was the best descriptive model for solar tunnel drying, open sun drying and greenhouse drying of all of the microalgae cultures.

\section{References}

Akpinar AK. Mathematical modeling and experimental investigation on sun and solar drying of white mulberry. J. of Mechanical Science and Techn. 2008; 22 pp: 1544-1553.

Babalis SJ, Papanicolaou E, Kyriakis N. and Belessiotis VG. Evaluation of thin layer drying models for describing drying kinetics of figs (Ficus carica). Journal of Food Engineering 2006; 75(2): 205-214.

Bala BK, Mondol MRA, Biswas BK, Das Chowdury BL, Janjai S. Solar Drying of Pineapple Using Solar Tunnel Dryer. Renewable Energy. 2003; 28. pp:183-190.

Diamente LM, Munro PA. Mathematical modeling of the thin layer solar drying of sweet potato slices. Solar Energy. 1993; 51. pp: 271-276.

Doymaz I. Suitability of thin-layer drying models for infrared drying of peach slices. Journal of food processing and preservation. 2014; 38 (6). pp: 2232-2239.

Elicin AK. and Sacllik K. An Experimental Study for Solar Tunnel Drying of Apple. Journal of Agricultural Sciences. 2005; 11 (2). pp:207-211.

Imre L. 1986. Technical and economical evaluation of solar energy. Drying Technology, 4, pp. 503-512

Midilli A, Kucuk H, Yapar Z. A new model for single layer drying. Dry Technol. 2002; 120 (7):1503-1513.

Sharaf-Elden YI, Blaisdell JL and Hamdy MY. A model for ear corn drying. Transactions of the ASAE. 1980; 5. 1261-1265

Soysal Y. Mathematical modeling and evaluation of microwave drying kinetics of mint (Mentha spicata L.). Journal of Applied Sciences. 2005; 5(7) pp: 1266-1274.

Stiling J, Li S, Stroeve P, Thompson J, Mjawa B, Kornbluth K, Barrett DM. Performance evaluation of an enhanced fruit solar dryer using concentrating panels. Energy for sustainable development. 2012; 16. 224-230.

Tiris C., Ozbalta N, Tiris M, Dincer İ.1994.Performance of a solar dryer. Energy, 19, pp. 993-997 
Toğrul IT. and Pehlivan D. Mathematical modeling of solar drying of apricots in thin layers. J. of Food Engineering. 2002; 55 pp:209-216.

Yaldiz O, Ertekin C and Uzun HI.. Mathematical modelling of thin layer solar drying of Sultana grapes. Energy. 2001; 26. 457-465. 